\title{
Nutrients: trace metals, micronutrients, oestrogen and B-vitamin content of Osun River: A River that runs southwestern Nigeria into the Atlantic Gulf of Guinea
}

\author{
Afolabi-Balogun, N.B. ${ }^{1}$; Oni-Babalola O.A ${ }^{1}$; Adeleke, I.I ${ }^{1}$; Oseni, F.A ${ }^{5}$; Bello R.H ${ }^{4}$.; Bashir, M². \\ and Raji B. $\mathrm{A}^{3}$
}

\begin{abstract}
${ }^{I}$ Molecular Biology \& Genetic Diversity Research Laboratory, Biochemistry Unit, Department of Chemical Sciences, College of Natural \& Applied Sciences, Fountain University, Osogbo, Osun State, Nigeria.

${ }^{2}$ Multiuser Research Laboratory, Faculty of Science, Ahmadu Bello University, Zaria, Kaduna-State, Nigeria.

${ }^{3}$ Department of Agronomy, Faculty of Agriculture, University of Ilorin, Kwara State, Nigeria.

${ }^{4}$ Department of Pharmaceutical Microbiology and Biotechnology, University of Ilorin, Ilorin, Kwara State, Nigeria.

${ }^{5}$ Department of Chemical Sciences, Yusuf Maitama Sule University, Kano State, Nigeria.
\end{abstract}

\section{Abstract}

Osun-Osogbo Grove has a long history of healing and therapeutic claims by adherent believers, in spite of advancement in medicine. Scientists made attempts at investigating the biodiversity of the Grove, till date, there has not been convergence point between science and these indigenous beliefs. This study identified the presence of therapeutic agents in the water of Osun-Osogbo River, paying attention to at least six parameters; vitamin, phosphate, nitrate, amino acid, hormone and trace metal. Water samples were taken from two different sites during pre, during and post raining sessions (April 2017 - September 2019) were analysed using High Performance Liquid Chromatography (HPLC), Gas Chromatography Mass Spectroscopy (GC-MS) and Atomic Absorption Spectrometer (AAS). Trace metal analysis revealed an average of $0.009-0.079 \mathrm{mg} / \mathrm{Kg}$ Zinc from site one and lower in site two. The mean value of manganese at both sites was virtually the same at $0.018-0.313 \mathrm{mg} / \mathrm{kg}$, aluminum content was $0.045-0.179 \mathrm{mg} / \mathrm{Kg}$ at site one, $0.050-0.192 \mathrm{mg} / \mathrm{kg}$ at site two, cobalt was $0.024 \mathrm{mg} / \mathrm{kg}$ at site one, $0.026 \mathrm{mg} / \mathrm{kg}$ at site two while nickel was $0.006 \mathrm{mg} / \mathrm{kg}$ and $0.004 \mathrm{mg} / \mathrm{kg}$ for site one and two respectively. HPLC analysis shows mean Methionine content at both sites is higher than the FDA (56.6 ug/mL); site one had $74.41 \mathrm{ug} / \mathrm{mL}$ while site two had $57.11 \mathrm{ug} / \mathrm{mL}$ The mean values of two water-soluble vitamins; Thiamine (B1) was $3.758 \mathrm{mg} / \mathrm{Kg}$ and $2.355 \mathrm{mg} / \mathrm{Kg}$ while Pyridoxine (B6) was $0.108 \mathrm{mg} / \mathrm{Kg}$ and $0.072 \mathrm{mg} / \mathrm{Kg}$ at site one and two. GCMS analysis of steroidal content revealed values below lowest observed effect level (LOEL), testosterone $(4.8 \mathrm{ng} / \mathrm{L})$ and estrogen $(2.4 \mathrm{ng} / \mathrm{L})$ were still elevated while ethinylestradiol and estriol were $\geq 1.5 \mathrm{ng} / \mathrm{L}$. Summarily, site one the major part for spiritual activities showed higher essential nutrient contents than site two which support the enrichment and potential therapeutic properties of the Osun river water. However, further scientific research is required to ensure that these therapeutic potentials supersede the toxicological effect. 


\section{Introduction}

Water is an essential nutrient for all known forms of life, it is also the medium by which fluid and electrolyte homeostasis is maintained in humans. The presence of liquid water on the surface is one of the key characteristics that make the Earth a unique planet, and it is usually considered to be critical for a planet to be habitable (Kasting, 2003). The composition of water varies widely with local geological conditions. Generally, all water bodies be it groundwater, surface water or any other forms have other chemical components dissolved in it. Water contains small amounts of gases, minerals and organic matter of natural origin (Sadgir and Vamanrao, 2003). Since water acquires its constituents from contact with rocks, soil and the environment, it is natural therefore to detect inorganic chemicals in drinking water that are occurring naturally. Drinking water supplies may contain some of these essential minerals naturally or through deliberate or incidental addition. Water supplies are highly variable in their mineral contents, while some contribute appreciable amounts of certain minerals either due to natural conditions (E.g., Ca, Mg, Se, F, Zn), intentional additions Fluorine (F), or leaching from piping copper $(\mathrm{Cu})$, most provide lesser amounts of nutritionally/essential minerals. (Olivares and UauyZ, 2000). Prominent amidst these constituents are micronutrients, which are nutrients, required by organisms throughout life in small quantities to orchestrate a range of physiological functions. These may include; vitamins, amino acids, minerals as well as metals of enzymatic importance. Micronutrients are vital for the proper functioning of all the body systems, enabling the body to produce enzymes, hormones, and other substances essential for proper growth and development. Although require in minute quantities, absence or decrease in quantities below body requirements may have consequences ranging from mild to severe (Hannah Ritchie 2017).

Nutrients and other life-sustaining elements delivered to water body systems are a major determinant of the functioning of such water body. Thus, the Oșun River that flows southwards through central Yoruba land in southwestern Nigeria into the Lagos Lagoon and the Atlantic Gulf of Guinea is expected to be rich in terms of micronutrients considering the climatic, and vegetation of its location. It is one of the several rivers ascribed in local mythology to have been, women who turned into flowing waters after some traumatic event frightened or angered them. Its main source is from Ilase, Osun State $7^{\circ} 44^{\prime} 34.5^{\prime \prime} \mathrm{N} 4^{\circ} 39^{\prime} 17.6^{\prime \prime} \mathrm{E}$. The river is named after the Oșun or Oshun, one of the most popular and venerated Orishas (Murrell, 2009). Oșun is one of the river goddesses in Yoruba land, she is believed by devotees to provide their needs, which ranges but not limited to ability to give barren women babies and change the lives of many other people. Hence, the river water is known for its ability to cure ailments/illnesses and solve fertility problems. 
There is growing concern on environmental issues and the supernatural power associated with Osun river water, mainly due to the fact that most report are unpublished and there are limited scientific information on both river constituent and its effects on believer who comes from far and near during the festival to collect water for various reasons. Olajiire and Imaokparia (2000 and 2001) reported the metals concentrations as well as inorganic nutrients of the Osun River, however, the concentrations of micronutrient in the river are uncertain. In addition to inorganic nutrients and trace metals, evaluation of the soluble B-vitamins (thiamin B1, riboflavin B2, pyridoxine B6, biotin B7 and cobalamin B12), hormone and the amino acid methionine is essential to give idea of the metabolic potential of the river water. Thus, this study is set out to identify, if any the presence of therapeutic agents/metabolic cofactors in the Osun River water.

\section{Method}

\section{Sampling Area}

This was conducted within the Osun - Osogbo Sacred grove which is located along the bank of Osun River in Osogbo capital city of Osun State, South Western Nigeria. It is located on a latitude of $7^{\circ} 45^{\prime} 05.9^{\prime \prime} \mathrm{N}$ and longitude of $4^{\circ} 33^{\prime} 03.9^{\prime \prime} \mathrm{E}$ as indicated (figure1), $250 \mathrm{~km}$ north of Lagos, land size of 75 hectares and about 350 metres above sea level. The Groves houses hundred shrines, sculptures and world heritage site (National Commission for Museums and Monuments (NCMM), 2005 and Osegale, et al. 2014).

\section{Collection of water samples}

Water samples were collected from two locations, namely; in the conserved region of the Grove with limited human activity Site $1\left(7^{\circ} 45^{\prime} 03.9^{\prime \prime} \mathrm{N}\right.$ and longitude of $\left.4^{\circ} 33^{\prime} 03.9^{\prime \prime} \mathrm{E}\right)$ and outside the Grove where there are unlimited activities, Site 2 (745'12.2"N 4³3'05.4"E) between April 2017 - September 2019 at 7am. Sample collection was subdivided to three, about $1000 \mathrm{~mL}$ each of water samples were collected in previously soaked with $10 \% \mathrm{HCL}$, washed with phosphate - free detergent, dried and pre - calibrated polythene screw capped plastic bottles. The remaining two portions were collected in clean high-density polyethylene (HDPE) dark bottles for vitamins analysis, amino acid assay as well as hormone content. All collected samples were immediately taken to the laboratory for analysis. 


\section{Sample Analysis}

\section{Macroscopic Analysis of water samples}

This was performed using the virtual and sensory evaluation method (Sharif et al., 2017). The colour, odour and the presence of foreign matters were observed.

\section{pH determination}

$\mathrm{pH}$ values of water samples were determined as described by (Raphael and Emmanuel, 2019). Prior to analysis, acidic and alkaline buffer solutions of $\mathrm{pH} 4$ and 7 were used for calibration, readings were taken and water samples with $\mathrm{pH}$ values of less than 7 were considered acidic, $\mathrm{pH}=7$; neutral and greater than 7 , alkaline.

\section{Metal Analysis}

Water samples was filtered through a $0.22 \mu \mathrm{m}$ polypropylene Calyx capsule filter and collected in lowdensity polyethylene (LDPE) bottles. Sample was further acidified to $\mathrm{pH}<2$ with ultrapure grade hydrochloric acid $(\mathrm{HCl})$ and stored cool for at least one month before extraction (Radulescu et al., (2014). Afterwards, samples were analysed using Atomic Absorption Spectrophotometer (AAS) as described by Smith, (1983).

\section{Vitamins and Methionine Analysis}

Vitamins and Methionine analysis were analysed using the liquid chromatographic method (Abano et al., (2014) and Cortés-Herrera et al., (2019). Water samples for vitamin and methionine analysis were filtered through $0.22 \mu \mathrm{m}$ polypropylene Calyx capsule filters and collected in high-density polyethylene (HDPE) dark bottles and stored frozen until analysis. Dissolved B-vitamins and methionine were extracted and pre-concentrated in solid-phase extraction onto a $\mathrm{C}_{18}$ resin before analysis.

\section{Nutrient Analysis}

Phosphate and nitrate analysis were performed according to the protocol described by Environmental Protection Agency, (2006). 


\section{Phosphate Analysis}

Standard solutions were prepared by accurately measuring $10 \mathrm{~mL}$ of the stock solution into a $250 \mathrm{~mL}$ volumetric flask and made up to volume with distilled $\mathrm{H}_{2} \mathrm{O}$. Varying volumes of the standard were then measured $(5 \mathrm{~mL}, 10 \mathrm{~mL}, 15 \mathrm{~mL}, 20 \mathrm{~mL}$ and $25 \mathrm{~mL}$ ) into separate labeled $100 \mathrm{~mL}$ volumetric flasks. The test water sample was diluted by a factor 10 , before $25 \mathrm{~mL}$ of diluted sample was been transferred to a $100 \mathrm{~mL}$ volumetric flask, then made to mark using dilute distilled water. All solutions were kept for 30 minutes to allow color development before reading absorbance at $880 \mathrm{~nm}$. Concentrations of the test samples were calculated from the standard curve.

\section{Nitrate Analysis}

Standard solutions were prepared by measuring $2 \mathrm{~mL}$ of the stock solution and made up to a $100 \mathrm{~mL}$ with distilled water. Varying volumes of the standard were measured into as separate beaker then interfering organic and metallic substances were removed by treating with $20 \mathrm{~mL}$ mercury (II) chloride solution. Two different volumes of each test sample were also subjected to similar treatment. All sample $\mathrm{pH}$ was adjusted to 11 with $50 \%$ sodium hydroxide $(\mathrm{NaOH})$, filtered to removed insoluble pellet. The initial flow through was discarded before allowing complete filtration. Then $2 \mathrm{~mL}$ of each filtrate was transferred into a beaker, and $1 \mathrm{~mL}$ of $1 \%$ sodium salicylate solution was added, mixed well, and left to evaporate to dryness. It was later dried in the oven for 20 minutes at $105^{\circ} \mathrm{C}$.

After removal from the oven, it was cooled, and then dissolved with $2 \mathrm{~mL}$ concentrated tetraoxosulphate (VI) acid $\left(\mathrm{H}_{2} \mathrm{SO}_{4}\right), 15 \mathrm{~mL}$ distilled water was added after the solution had cooled to room temperature followed by addition of $15 \mathrm{~mL}$ of the sodium hydroxide - potassium sodium tartrate. The mixture was allowed to stand at room temperature for one hour and absorbance read at $420 \mathrm{~nm}$.

\section{Oestrogen Analysis}

River water samples were prepared as described by Xiao et al 2001 using $8 \mathrm{ng} / \mathrm{L}$ estradiol II as internal control in each calibrated sample. The samples were then subjected to GCMS using the spitless technique, using $0.75 \mathrm{~min}$ period on an HP-5MS capillary column (15 m x $0.25 \mathrm{~mm}$ I.D., $0.25 \mathrm{~mm}$ film thickness) and 5\% diphenyl - 95\% dimethyl siloxane liquid phase. The oven temperature was maintained at $65^{\circ} \mathrm{C}$ for $1 \mathrm{~min}$ and then programmed to $220^{\circ} \mathrm{C}$ at $40^{\circ} \mathrm{C}$ per min, then to $255^{\circ} \mathrm{C}$ at $5^{\circ} \mathrm{C}$ per min and finally to $330^{\circ} \mathrm{C}$ at $20^{\circ} \mathrm{C}$ per min and maintained at $330^{\circ} \mathrm{C}$. The injector and transfer lines were 
$330^{\circ} \mathrm{C}$. Methane $(99.99 \%)$ was used as the reagent gas in the negative ion mode with source pressure of $160 \mathrm{~Pa}$.

\section{Result}

\section{Sampling Area}

Site one which is the major spiritual site of the grove with high natural conserved habitant, natural conservation, while site two is the area under the suspended bridge with minimal conservation as well as increased human and animal activities. Generally, the water body was free of macro - aquatic plantlike organisms and free flowing.

Table 1 shows the macroscopic (color, odour and foreign matter) characteristics and $\mathrm{pH}$ values for water samples collected from both sites. Both samples had similar characteristics with site 1 having a slightly high alkaline $\mathrm{pH}$.

\section{Sample Analysis}

\section{Metal Analysis}

Plate I show a screenshot of the result of metal analysis, it showed that the average zinc content in site one was $0.079 \mathrm{mg} / \mathrm{Kg}$, while that of site two was below detection. The manganese (Mn) content was practically the same for both sites, while the Nickel (Ni), Cobalt (Co) and Aluminum (Al) levels were almost the same throughout the study period for both sites.

\section{Vitamins and Methionine Analysis}

Vitamins and methionine content of the river water is represented (Table 1), the average Methionine content at site one was $74.41 \mathrm{ug} / \mathrm{mL}$ while site two was $57.11 \mathrm{ug} / \mathrm{mL}$. The mean values of two watersoluble vitamins; Thiamine (vitamin B1) content of site one was $3.758 \mathrm{mg} / \mathrm{Kg}$ and $2.355 \mathrm{mg} / \mathrm{Kg}$ at site two and B6 (Pyridoxine) was $0.108 \mathrm{mg} / \mathrm{Kg}$ in site one and $0.072 \mathrm{mg} / \mathrm{Kg}$ at site two.

\section{Nutrient Analysis}

Phosphate and nitrate analysis done on the water sample yielded relatively lower concentrations in the water as shown in Plate 1. Average phosphate content of site 1 (s1) was observed to be $0.027 \mathrm{mg} / \mathrm{Kg}$ while Nitrate content was $0.082 \mathrm{mg} / \mathrm{Kg}$. 


\section{Oestrogen Content}

Over the stretch of the study period, the hormone values declined during the raining session by half from their maximum values for testosterone $(4.8 \mathrm{ng} / \mathrm{L})$, estrone $(8.8 \mathrm{ng} / \mathrm{L})$, ethinylestradiol $(6.1 \mathrm{ng} / \mathrm{L})$, and estrogen $(4.9 \mathrm{ng} / \mathrm{L})$ in site 1 estrogen $(4.8 \mathrm{ng} / \mathrm{L})$ and ethinylestradiol $(2.4 \mathrm{ng} / \mathrm{L})$ while estrogen was about $\geq 1.5 \mathrm{ng} / \mathrm{L}$ in site 2 .

Over the same stretch, the hormone values declined by half from their maximum mean values for testosterone (3.3 ng/L), estriol (8.8 ng/L), ethinylestradiol (6.1 ng/L), and estrogen (4.9 ng/L). From 67 to $100 \mathrm{~km}$ mark, testosterone $(4.8 \mathrm{ng} / \mathrm{L})$ and estrogen $(2.4 \mathrm{ng} / \mathrm{L})$ were still elevated while ethinylestradiol and estriol were $\geq 1.5 \mathrm{ng} / \mathrm{L}$.

\section{Discussion}

The potential contributions of drinking water to nutritional status also depend on water consumption, which is highly variable depending on both behavioral factors, believe, climatic as well as environmental conditions. Individuals with relative water consumption rate include infants, residents of hot climate, individual physiologically assumed to be susceptible to dehydration and individuals engaged in strenuous physical activity. The Osun Osogbo Heritage Grove is a major site of tourist attraction due to various beliefs that the water from the river possess the ability to heal and aid fertility. These beliefs led to thousands of devotees use the Osun river water for their daily needs such as drinking and bathing. Despite the growing concern on environmental issues and the increasing efforts on environmental monitoring and research, information on both river water composition and its quantity are fragmented and mostly gathered in unpublished reports. Thus, this research was carried out to give a background scientific knowledge on the constituents of the river, which are likely to aid understanding the role of some of these constituents in the acclaimed properties of the river water. Principal investigation of the micronutrient was based on their role in metabolism and in fertility (UNICEF/UNU/WHO 1999).

The results from this study revealed that the Osun river water is slightly brownish and highly alkaline $\mathrm{pH}$. This slightly brownish might be attributed to the environmental pressure due to human activities from settlements along the river and rituals performed during festival that attract thousands of people (NCMM, 2005) and other anthropogenic factors which affect the properties of the water (Khatri and Tyagi 2015). While the alkaline $\mathrm{pH}=10.1$ of site 1 is higher when compared with Zamzam water with pH 8 (Shomar, 2012) and Mediterranean Sea water pH 8 (Flecha, 2015). Alkaline water are rich in 
minerals and attributed with health benefits such as ability to balance body $\mathrm{pH}$, antioxidant, detoxification properties and generally optimised body immunity (Mousa, 2017). This could be attributed to the therapeutic value of the Osun River.

The presence of vitamins in drinking water has been of particular interest due to the role vitamins play in metabolism, especially the vitamin B complex family known to play significant role as cofactor in enzyme catalyzed reaction such as dehydrogenase complexes (Parra et al.,2018). Prominent among these vitamins are thiamine used in the synthesis of the cofactor Thiamine pyprophosphostate, pyridoxine and its role in the glycogen synthesis pathway as well as amino acid metabolism. In this study, the vitamins and methionine concentrations along the Osun river follow different trend, for instance, site one was observed to be richer in methionine $(74.410 \mathrm{~g} / \mathrm{Kg})$, thiamine $(3.75823 \mathrm{~g} / \mathrm{Kg})$ and pyridoxine $(0.108020 \mathrm{~g} / \mathrm{Kg} ; 0.622776 \mathrm{~g} / \mathrm{Kg})$ when compared with site two where methionine (54.11 $\mathrm{g} / \mathrm{Kg})$, thiamine $(2.35473 \mathrm{~g} / \mathrm{Kg})$, pyridoxine $(0.0715691 \mathrm{~g} / \mathrm{Kg})$ values were detected respectively.

Conversely, an increase of vitamin B1 and B6 is observed in site one, when compared with site two, however, the values were lower than those reported for Moulouya river by Tovar-Sanchez et al. (2016), other vitamins such as B12 were not detected in the water samples. Opposite responses in the various B-vitamins is not rare since their availability in water is governed by the specificity of the predominant phytoplankton species for those vitamins (Sanudo-Wilhelmy et al. 2012). In this study, different values of vitamins (i.e., B1 and B6) were observed in the main worship area where the phytoplankton assemblages changed from dominance of diatoms to dinoflagellates mainly due to the fact that devotees tend to continuously drop sacrifice at this portion of the river. These might also give basis for the consistence slight brown coloration of the Osun water, going by the ability of dinoflagellates to generate "red tides". In their report, Radi, et al. (2007) established the relationship between dinoflagellate cyst assemblages and hydrographic conditions, productivity and nutrient concentrations, they suggested that dinoflagellate cyst assemblages can be used to reconstruct primary productivity, temperature and salinity. Sa nudo-Wilhelmy et al. (2014) emphasized the regulatory role of Vitamins in metabolic activities of marine plankton. Because of their high bacterial activities, freshwater sources (such as rivers and groundwater) are considered important sources of vitamin B1 and B6 (Barada et al., 2013; Gobler et al., 2007; Okbamichael and Sa nudo-Wilhelmy, 2005).

The National Agricultural Library reported the role of trace metals such as: zinc, copper, manganese, etc. in the influence on reproduction and development. In a similar report by (Rasheed et al., 2003), $\mathrm{NO}_{3}{ }^{-}$and $\mathrm{PO}_{4}{ }^{3-}$ were reported to play an important role in biochemical processes. Looking at the trace 
metal zinc, the value $0.079 \mathrm{~g} / \mathrm{Kg}$ was obtained for site one, and $-0.015 \mathrm{~g} / \mathrm{Kg}$ for site two. Zinc, an essential metal which is needed for hormone regulation, immune builder and fertility in women was detected in the river sample at $7 \mathrm{mg}$ in each litre of water taken from the river, compared with standard FDA value of (3-5) mg/L. Aluminum content was observed to be $0.179 \mathrm{~g} / \mathrm{Kg}$, site one and $0.192 \mathrm{~g} / \mathrm{Kg}$ for site two, compared with standard FDA value of $0.05-0.2 \mathrm{mg} / \mathrm{L}$; this implies that for every litre of Osun water taken, $0.2 \mathrm{mg}$ of aluminum is contained in it. The concentration of $\mathrm{Cr}$ in surface water represents the industrial activity (Shiller and Boyle, 1987). Surface water contains chromium in the range of 0.004 to $0.007 \mathrm{mg} / \mathrm{L}$ (Batayneh, 2012). The chromium, cadmium, copper and lead levels in the Osun River water were below detection indicating that the water from the River has zero concentration. Manganese (Mn) is the essential component of those biochemical reactions that affects bone, cartilage, brain and energy supply but toxic in higher concentration. Manganese in freshwater ranges from 1 to $200 \mu \mathrm{g} / \mathrm{L}$. In this present study, the concentration of Mn determined was $0.313 \mathrm{~g} / \mathrm{Kg}$ for both sites (Plate I) and do not exceed the FAO/WHO permissible limits for drinking water. Arsenic was $0.842 \mathrm{~g} / \mathrm{Kg}$ for site one, and $0.569 \mathrm{~g} / \mathrm{Kg}$ for site two, compared with $7.29 \mathrm{~g} / \mathrm{L}$ reported by Fahad et al. (2016) for Zamzam. Although arsenic may cause low birth weight and spontaneous abortion, long-term chronic health effects, such as skin disease, skin cancer, it was and is still applied for pharmaceutical and medical purposes in curing asthma and hematological illnesses. In their report, Stein and Tallman (2012) described the use of Arsenic trioxide (ATO) as a new era in chemotherapeutic of acute promyelocytic leukemia (APL). A growing body of literature demonstrates the feasibility and efficacy of ATO, usually given with ATRA, in the treatment of patients with newly diagnosed APL. However, he mentioned reports of potential unintended toxicities, which included impaired fertility in both men and women. Walsh in his (2003) Second edition textbook of Biopharmaceutical Biochemistry and Biotechnology also describe biologic agent as any other trivalent organic arsenic compound applicable to the prevention, cure or treatment of disease or conditions of human beings.

Copper, cadmium, and lead had relatively no value $(-0.006 \mathrm{~g} / \mathrm{Kg})$ when tested for in the Osun water; knowing that lead is harmful to the body, it was satisfactory to know the lead content of the Osun water was below detectable level throughout the period of study. Phosphate $\left(\mathrm{PO}_{4}{ }^{3-}\right)$ value observed from the Osun water did not exceed the stipulated standard of $0.02 \mathrm{~g} / \mathrm{Kg}$, as the value obtained was $0.027 \mathrm{~g} / \mathrm{Kg}$. The $\mathrm{NO}_{3}{ }^{-}$value obtained was $0.082 \mathrm{~g} / \mathrm{Kg}$. In summary, it was observed that higher nutrients levels were obtained from the first site, which is within the grove and the believed center of most of the spiritual activities of the devotees, and this is due to the natural conservation present over the river. Occurrence of metals such as $\mathrm{Cu}, \mathrm{Zn}$ and $\mathrm{Fe}$ in water is also of importance considering the role of 
metals as cofactors of enzymatic activities and protein structure. In natural surface waters, the concentration of zinc is usually below $0.010 \mathrm{mg} / \mathrm{L}$, while in groundwater $0.010-0.040 \mathrm{mg} / \mathrm{L}(\mathrm{Nriagu}$ 1980; Elinder 1986). Essential amino acids such as methionine found in some water bodies has be attributed to environment or climatic conditions of the water. Micronutrients indirectly serve as the catalyst to release the energy from the macronutrients.

After obtaining the values $74.410 \mu \mathrm{g} / \mathrm{mL}$ for the first site, and $57.110 \mu \mathrm{g} / \mathrm{mL}$ for the second site, and knowing that methionine is an essential amino acid required for initiation of protein synthesis. It was satisfactory to know the methionine content is high when compared with standard FDA value 56.6 $\mu \mathrm{g} / \mathrm{mL}$. This might imply that an individual taking Osun water takes in over $55 \mu \mathrm{g}$ of water dissolved methionine per every $\mathrm{mL}$ of the water. Vitamin B1 (Thiamine) content gotten in site one was $3.758 \mu \mathrm{g} / \mathrm{mL}$ and site two was $2.355 \mu \mathrm{g} / \mathrm{mL}$ compared with standard of $1.5 \mathrm{mg} / 1$. Hence, it shows that if one takes a $\mathrm{mL}$ of Osun water, the thiamine content obtained from it is over $3 \mu \mathrm{g}$ compared with the RDA value of 1.1mg. Vitamin B6 (Pyridoxine) value obtained was $0.108 \mu \mathrm{g} / \mathrm{mL}$ for site one, while $0.072 \mu \mathrm{g} / \mathrm{mL}$ was observed for site two, and this shows that for every $\mathrm{mL}$ of the Osun water taken in, $0.1 \mu \mathrm{g}$ of pyridoxine is contained in it. Due to the high bacterial activities, freshwater sources (such as rivers and groundwater) are considered important sources of vitamin $\mathrm{B}_{1}$ and $\mathrm{B}_{6}$ and Baren-cohen et al, (2006) reported that hormones in readily measured quantities can be transported along a considerable distance from the source of pollution.

Several literatures have shown that steroid hormones produced by humans and animals constantly excreted into the environment found their ways into underground water and rivers (Lintelmann et al., 2003; Drewes and Shore, 2001; Shore and Shemesh, 2003). This work concentrated on naturally occurring hormones such as estrone $\left(E_{1}\right)$ and estradiol-17b $\left(E_{2}\right)$ which were reported to exert physiological effect at concentrations above LOEL (Lowest observable effect level). $E_{2}$ is abiotically converted to $E_{1}$ thus, they are generally considered as oestrogen. The LOEL for $E_{2}$ and $E_{1}$ were report as 14 and $3.3 \mathrm{ng} / \mathrm{L}$, respectively (Olsen et al., 2007) while ethinylestradiol is $1 \mathrm{ng} / \mathrm{L}$ (Baren-cohen et $a l$, 2006). The mean values of steroid detected in the Osun River water over the study period shows the hormone content were lower doing pre-raining season, but the content was both above the LOEL. Ethinyl estradiol binds to the estrogen receptor complex and enters the nucleus, activating DNA transcription of genes involved in estrogenic cellular responses. This agent also inhibits 5-alpha reductase in epididymal tissue, which lowers testosterone levels and may delay progression of prostatic cancer. In addition to its antineoplastic effects, ethinyl estradiol protects against osteoporosis. 
In animal models, short-term therapy with this agent has been shown to provide long-term protection against breast cancer, mimicking the antitumor effects of pregnancy

In conclusion, this study established micronutrient, trace metals, water soluble vitamin, hormone content as well as other dissolved trace metals, $\mathrm{Pb}, \mathrm{Cd}, \mathrm{As}, \mathrm{Zn}, \mathrm{Cu}, \mathrm{Ni}, \mathrm{Co}, \mathrm{Fe}, \mathrm{Mn}, \mathrm{Cr}$ and $\mathrm{PO}^{4}$ which were within the acceptable limits. Hence, maybe associated with metabolic and physiological processes leading to the therapeutic claims of the ancient River.

\section{Reference}

Abano, E. E., \& Godbless Dadzie, R. (2014). Simultaneous detection of water-soluble vitamins using the High Performance Liquid Chromatography (HPLC) - a review. Croatian Journal of Food Science and Technology, 6(2), 116-123. https://doi.org/10.17508/cjfst.2014.6.2.08

Antonio Tovar-Sanchez, Gotzon Basterretxea, Mostapha Ben Omar, Antoni Jordi, David Sanchez Quiles, Mardjan Makhani, Daoudi Mouna, Cedrick Muya, Silvia Angles (2016). Nutrients, trace metals and B-vitamin composition of the Moulouya River: A major North African river discharging into the Mediterranean Sea. Estuarine, Coastal and Shelf Science $176: 47 \mathrm{e} 57$.

Barada, L. P., Cutter, L., Montoya, J. P., Webb, E. A., Capone, D. G., \& Sañudo-Wilhelmy, S. A. (2013). The distribution of thiamin and pyridoxine in the western tropical North Atlantic Amazon River plume. Frontiers in Microbiology, 4. doi:10.3389/fmicb.2013.00025

Barel-Cohen, K., Shore, L. S., Shemesh, M., Wenzel, A., Mueller, J., \& Kronfeld-Schor, N. (2006). Monitoring of natural and synthetic hormones in a polluted river. Journal of Environmental Management, 78(1), 16-23. doi: 10.1016/j.jenvman.2005.04.006

Batayneh A.M (2012) Toxic (aluminum, beryllium, boron, chromium and zinc) in groundwater: health risk assessment. Int. J. Environ. Sci. Technol. (2012) 9:153-162 DOI 10.1007/s13762-0110009-3

Cornely, K. (2004). Biopharmaceuticals: Biochemistry and Biotechnology, 2nd edition: Walsh, Gary, John Wiley \& Sons. Biochemistry and Molecular Biology Education, 32(2), 137138. doi:10.1002/bmb.2004.494032029997.

Cortés-Herrera, C., Artavia, G., Leiva, A., \& Granados-Chinchilla, F. (2019). Liquid chromatography analysis of common nutritional components, in feed and food. Foods, 8(1). https://doi.org/10.3390/foods8010001

Drewes, J.E., Shore, L.S., (2001). Concerns about pharmaceuticals in water reuse, groundwater recharge, and animal waste. In: Daughton, C.G., Jones-Lepp, T. (Eds.), Pharmaceuticals and 
personal care products in the environment: scientific and regulatory issues Symposium Series 791 . American Chemical Society, Washington, DC.

Environmental Protection Agency. (2006). Chapter 10: Nutrients -- Nitrogen and Phosphorus. In Volunteer Estuary Monitoring Manual (pp. 1-17).

Elinder C (1986) Handbook on the toxicology of metals, 2nd edn. Elsevier Science Publishing, Amsterdam.

Flecha, S., Pérez, F. F., García-Lafuente, J., Sammartino, S., Ríos, A. F., \& Huertas, I. E. (2015). Trends of pH decrease in the Mediterranean Sea through high frequency observational data: indication of ocean acidification in the basin. Scientific Reports, 5(1). doi:10.1038/srep 16770

Hannah Ritchie (2017) - "Micronutrient Deficiency". Published online at OurWorldInData.org. Retrieved from: 'https://ourworldindata.org/micronutrient-deficiency' [Online Resource]

Gobler CJ, Norman C, Panzeca C, Taylor GT, Sañudo-Wilhelmy SA (2007) Effect of B-vitamins (B1, B12) and inorganic nutrients on algal bloom dynamics in a coastal ecosystem. Aquat Microb Ecol 49:181-194. https://doi.org/10.3354/ame01132

Khatri, N., \& Tyagi, S. (2015). Influences of natural and anthropogenic factors on surface and groundwater quality in rural and urban areas. Frontiers in Life Science, 8(1), 23-39. https://doi.org/10.1080/21553769.2014.933716

Kasting JF, Catling D. (2003). Evolution of a habitable planet. Annu. Rev. Astron. Astrophys. 41, 429-463. (doi:10.1146/annurev.astro.41.071601.170049) Crossref, Google Scholar

Lintelmann, L., Katayama, A., Kurihara, N., Shore, L., Wenzel, A., (2003). Endocrine disruptors in the environment (IUPAC Technical Report). Pure Appl. Chem. 75, 631-681.

Mousa, H. A. (2017). Health Effects of Alkaline Diet and Water, Reduction of Digestive-tract Bacterial Load, and Earthing. Alternative Therapies, 22(April), 23-44.

Murrell, Nathaniel Samuel (2009). Afro-Caribbean Religions: An Introduction to Their Historical, Cultural, and Sacred Traditions. Temple University Press. ISBN 9781439901755.

National Commission for Museums and Monuments (NCMM). (2005). Nomination to the World Heritage List of Osun-Osogbo Sacred Grove, Osogbo, Osun State, Nigeria. Retrieved from https://whc.unesco.org/uploads/nominations/1118.pdf

Nriagu J (1980) Zinc in the environment, part I, ecological cycling. Wiley, New York.

Okbamichael, M., \& Sañudo-Wilhelmy, S. A. (2004). A new method for the determination of Vitamin B $_{12}$ in seawater. Analytica Chimica Acta, 517(1-2), 33-38. doi:10.1016/j.aca.2004.05.020

Olajire, A. A., \& Imeokparia, F. E. (2001). Water Quality Assessment of Osun River Environmental Monitoring and Assessment, 69(1), 17-28. doi:10.1023/a:1010796410829 
Olivares, M., Araya, M. and Uauy, R. (2000) Copper homeostasis in infant nutrition: deficit and excess.

J. Pediat. Gastroenterol. Nutr. 31(2), 102-111.

Olsen, P., Bach, K., Barlebo, H. C., Ingerslev, F., Hansen, M., \& Sørensen, B. H. (2007). Leaching of

Estrogenic Hormones from Manure-Treated Structured Soils. Environmental Science \& Technology, 41(11), 3911-3917. doi:10.1021/es0627747

Osegale, G. ., Omisore, E. ., \& Gbadegesin, J. T. (2014). Exploratory survey on the maintenance of Osun Osogbo sacred grove, Nigeria. African Journal of Hospitality, Tourism and Leisure, 3(2), 1-22.

Parra, M., Stahl, S., \& Hellmann, H. (2018). Vitamin B 6 and Its Role in Cell Metabolism and Physiology. Cell, 7, 84-108. https://doi.org/10.3390/cells7070084

Radi, Taoufik; Pospelova, Vera; Anne, de Vernal and Barrie, James. (2007). Dinoflagellate cysts as indicators of water quality and productivity in British Columbia estuarine environments. Marine Micropaleontology. 62. 269-297.

Rasheed, M., Badran, M. I., \& Huettel, M. (2003). Influence of sediment permeability and mineral composition on organic matter degradation in three sediments from the Gulf of Aqaba, Red Sea.

Estuarine, Coastal and Shelf Science, 57(1-2), 369-384. doi:10.1016/s0272-7714(02)00362-1.

Sa nudo-Wilhelmy, S.A., Cutter, L.S., Durazo, R., Smail, E.A., G!omez-Consarnau, L., Webb, E.A., Prokopenko, M.G., Berelson, W.M., Karl, D.M., (2012). Multiple B-vitamin depletion in large areas of the coastal ocean. Proc. Natl. Acad. Sci.

Sadgir P, Vamanrao A (2003) Water in Vedic literature. In: Abstract proceedings of the 3rd international Water history association conference, Alexandria. http://www.iwha.net/a_abstract.htm

Sanudo-Wilhelmy, S. A., Cutter, L. S., Durazo, R., Smail, E. A., Gomez-Consarnau, L., Webb, E. A., Karl, D. M. (2012). Multiple B-vitamin depletion in large areas of the coastal ocean. Proceedings of the National Academy of Sciences, 109(35), 14041-14045. doi:10.1073/pnas.1208755109

Sharif MK, Butt, SM., Sharif HR. and Nasir, M. (2017). Sensory Evaluation and Consumer Acceptability. pp 22 - 27. 17.

Shiller and Boyle (1987) Variability of dissolved trace metals in the Mississippi River. Geochimica ei Cosmochimica Acta Vol. 51, pp. 3273-3217

Shomar B. 2012. Zamzam water: concentration of trace elements and other characteristics. Chemosphere, 86 (6): 600-805

Shore, L.S., Shemesh, M., (2003). Naturally produced steroid hormones and their release into the environment. Pure Appl. Chem. 75, 1859-1871.

Smith, R. (1983). A laboratory manual for the determination of metals in water and wastewater by atomic absorption spectrophotometry. 
Stein, E. M., \& Tallman, M. S. (2012). Does arsenic trioxide impact fertility? Leukemia \& Lymphoma, 53(11), 2099-2100. doi:10.3109/10428194.2012.685737

Tovar-Sánchez, A., Basterretxea, G., Ben Omar, M., Jordi, A., SánchezQuiles, D., Makhani, M., Mouna, D., Muya, C., Anglès, S., 2016. Nutrients, trace metals and B-vitamin composition of the Moulouya River: a major North African river discharging into the Mediterranean Sea. Estuar. Coast. Shelf Sci. https://doi.org/10.1016/j.ecss.2016.04. 006.

UNICEF/UNU/WHO. Composition of a multi-Micronutrient supplement to be used in pilot programmes among pregnant women in developing countries. Report of a Workshop. New York, UNICEF, 1999.

Walsh, G (2003) Biopharmaceutical Biochemistry and Biotechnology. Biochemistry and Molecular Biology Education, 2004 Second Edition 1998 u John Wiley \& Sons: 


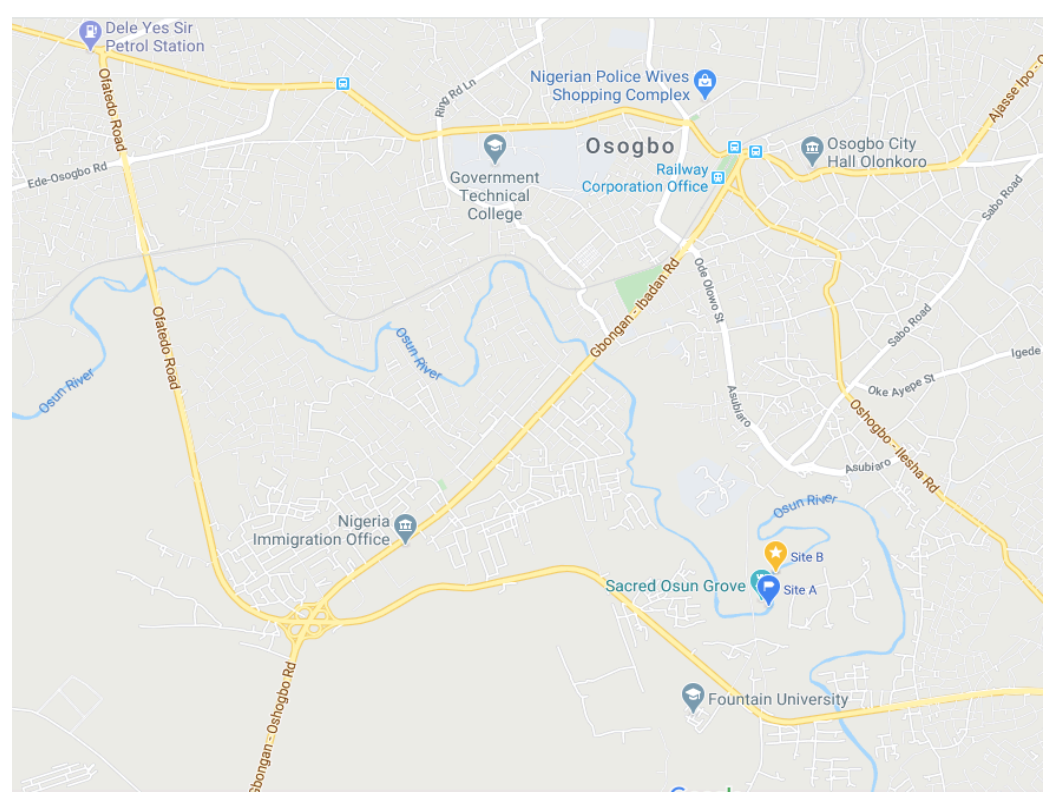

Figure 1: Graphical location of sampling location along the Osun River Path

Source: Map Data@2020 (maps.google.com)

\begin{tabular}{|c|c|c|c|c|c|c|c|}
\hline Date Time & Label & Element Label (nm) & Conc & \%RSD & Unadjusted Conc & Intensity & \%RSD \\
\hline 6/6/2017 13:21:19 & Site 2 & Al $(396.152 \mathrm{~nm})$ & 0.192 (ppm) & 1.96 & 0.192 (ppm) & 4834.446 & 2.04 \\
\hline |6/6/2017 13:07:31 & Site 1 & Zn (213.857 nm) & $0.079(\mathrm{ppm})$ & 3.84 & 0.079 (ppm) & | 1235.343 & 3.49 \\
\hline 6/6/2017 13:07:31 & Site 1 & $\mathrm{Cd}(228.802 \mathrm{~nm})$ & $0.000 \mathrm{u}(\mathrm{ppm})$ & $>100.00$ & $0.000(\mathrm{ppm})$ & -2.164 & $>100.00$ \\
\hline 6/6/2017 13:07:31 & Site 1 & Cu (324.754 nm) & $-0.261 u(\mathrm{ppm})$ & 1.34 & -0.261 (ppm) & -13801.281 & 1.34 \\
\hline 6/6/2017 13:07:31 & Site 1 & $\mathrm{Ni}(352.454 \mathrm{~nm})$ & 0.006 (ppm) & 3.98 & 0.006 (ppm) & 118.935 & 3.95 \\
\hline 6/6/2017 13:07:31 & Site 1 & Co $(340.512 \mathrm{~nm})$ & 0.024 (ppm) & 2.02 & 0.024 (ppm) & 291.971 & 1.99 \\
\hline 6/6/2017 13:07:31 & Site 1 & $\mathrm{~Pb}(405.781 \mathrm{~nm})$ & $-0.001 \mathrm{u}(\mathrm{ppm})$ & $>100.00$ & $-0.001(\mathrm{ppm})$ & -2.796 & $>100.00$ \\
\hline 6/6/2017 13:07:31 & Site 1 & $\operatorname{Mn}(403.076 \mathrm{~nm})$ & $0.313(\mathrm{ppm})$ & 0.56 & $0.313(\mathrm{ppm})$ & 11614.817 & 0.51 \\
\hline 6/6/2017 13:07:31 & Site 1 & $\operatorname{Cr}(425.433 \mathrm{~nm})$ & $0.000(\mathrm{ppm})$ & $>100.00$ & $0.000(\mathrm{ppm})$ & 2.089 & $>100.00$ \\
\hline 6/6/2017 13:07:31 & Site 1 & Al (396.152 nm) & 0.179 (ppm) & 2.32 & 0.179 (ppm) & 4508.113 & 2.41 \\
\hline 6/6/2017 13:21:19 & Site 2 & $\mathrm{Zn}(213.857 \mathrm{~nm})$ & $-0.015 u(\mathrm{ppm})$ & 2.28 & -0.015 (ppm) & -254.419 & 2.28 \\
\hline 6/6/2017 13:21:19 & Site 2 & $\mathrm{Cd}(228.802 \mathrm{~nm})$ & $-0.003 u(\mathrm{ppm})$ & 60.49 & $-0.003(\mathrm{ppm})$ & -35.049 & 60.49 \\
\hline 6/6/2017 13:21:19 & Site 2 & Cu (324.754 nm) & $-0.222 u(\mathrm{ppm})$ & 0.35 & -0.222 (ppm) & -11742.247 & 0.35 \\
\hline |6/6/2017 13:21:19 & Site 2 & $\mathrm{Ni}(352.454 \mathrm{~nm})$ & $0.004(\mathrm{ppm})$ & 2.19 & 0.004 (ppm) & 79.570 & 2.18 \\
\hline |6/6/2017 13:21:19 & Site 2 & Co (340.512 nm) & 0.026 (ppm) & 1.55 & 0.026 (ppm) & 317.639 & 1.52 \\
\hline 6/6/2017 13:21:19 & Site 2 & $\mathrm{~Pb}(405.781 \mathrm{~nm})$ & $-0.006 u(\mathrm{ppm})$ & 10.44 & -0.006 (ppm) & -23.467 & 10.44 \\
\hline |6/6/2017 13:21:19 & Site 2 & $\operatorname{Mn}(403.076 \mathrm{~nm})$ & $0.313(\mathrm{ppm})$ & 0.14 & $0.313(\mathrm{ppm})$ & 11616.365 & 0.12 \\
\hline 6/6/2017 13:21:19 & Site 2 & $\operatorname{Cr}(425.433 \mathrm{~nm})$ & $-0.002 u(\mathrm{ppm})$ & 9.59 & $-0.002(\mathrm{ppm})$ & -76.362 & 9.59 \\
\hline
\end{tabular}

Plate 1: A screenshot of trace metal analysis for both sites. 

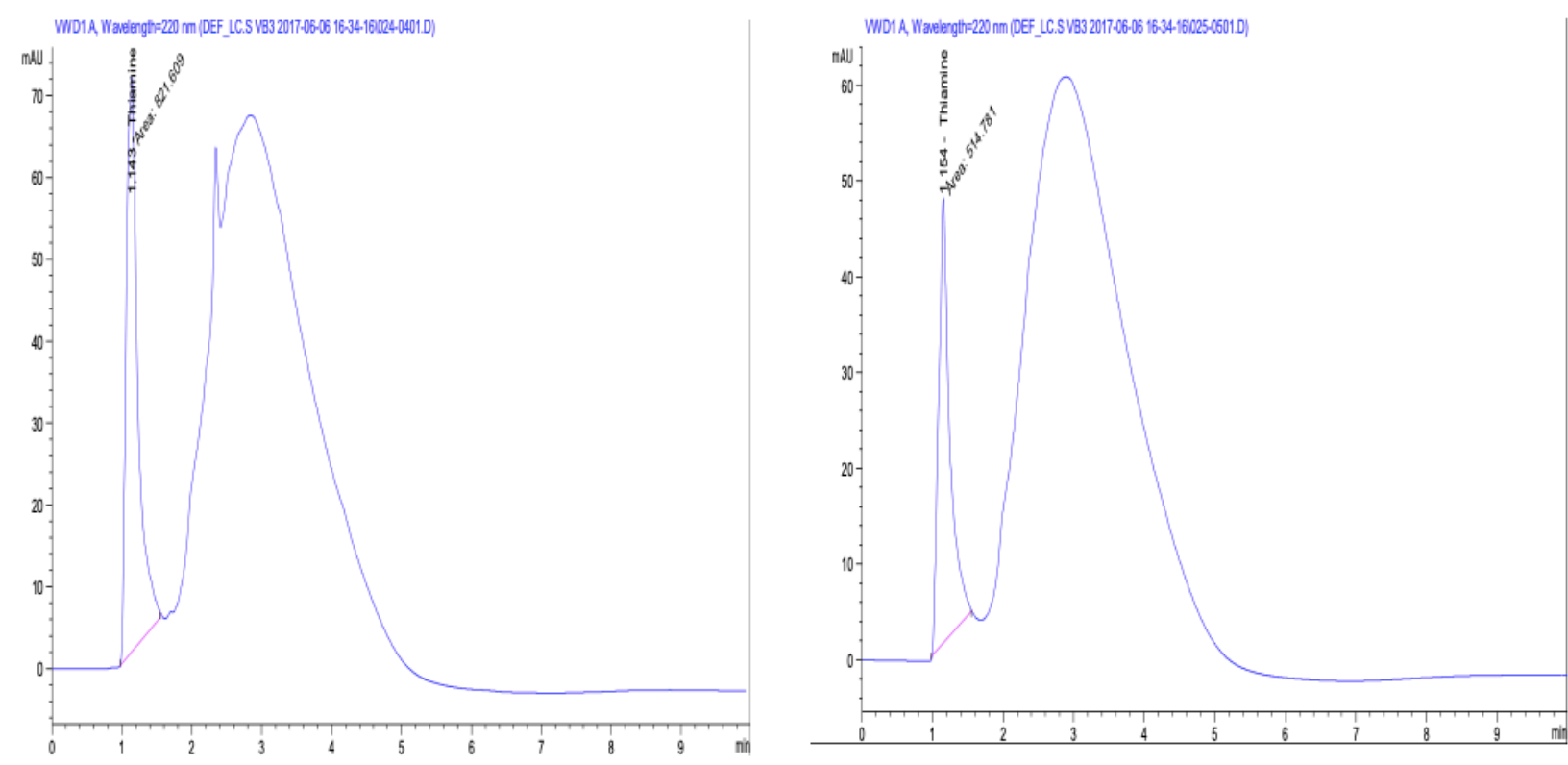

Figure 1: HPLC Spectra of Thiamine Content of Site 1(a) and 2 (b)
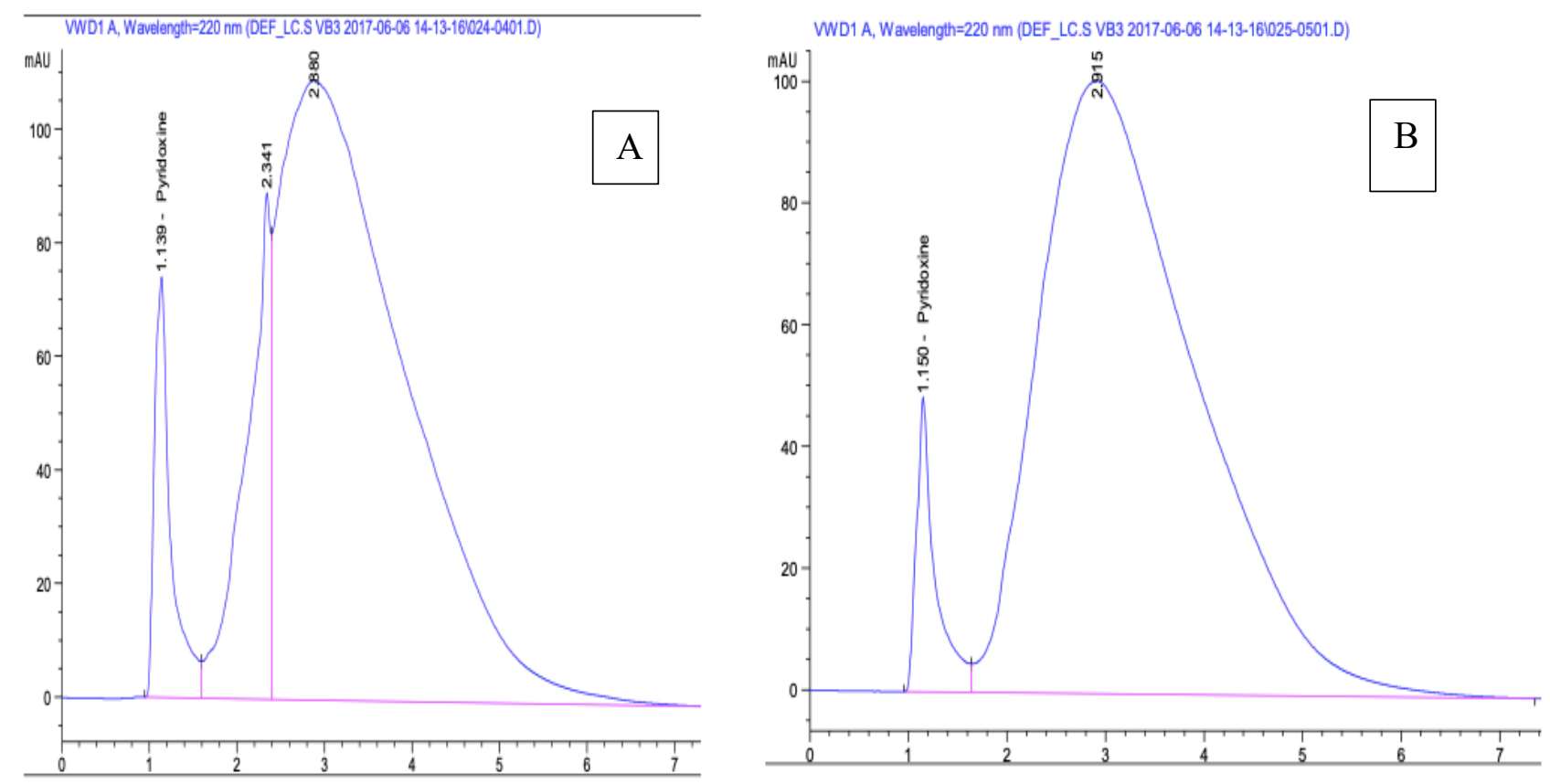

Figure 2: HPLC Spectra of Pyridoxine content of Site 1 (a) and 2 (b) 

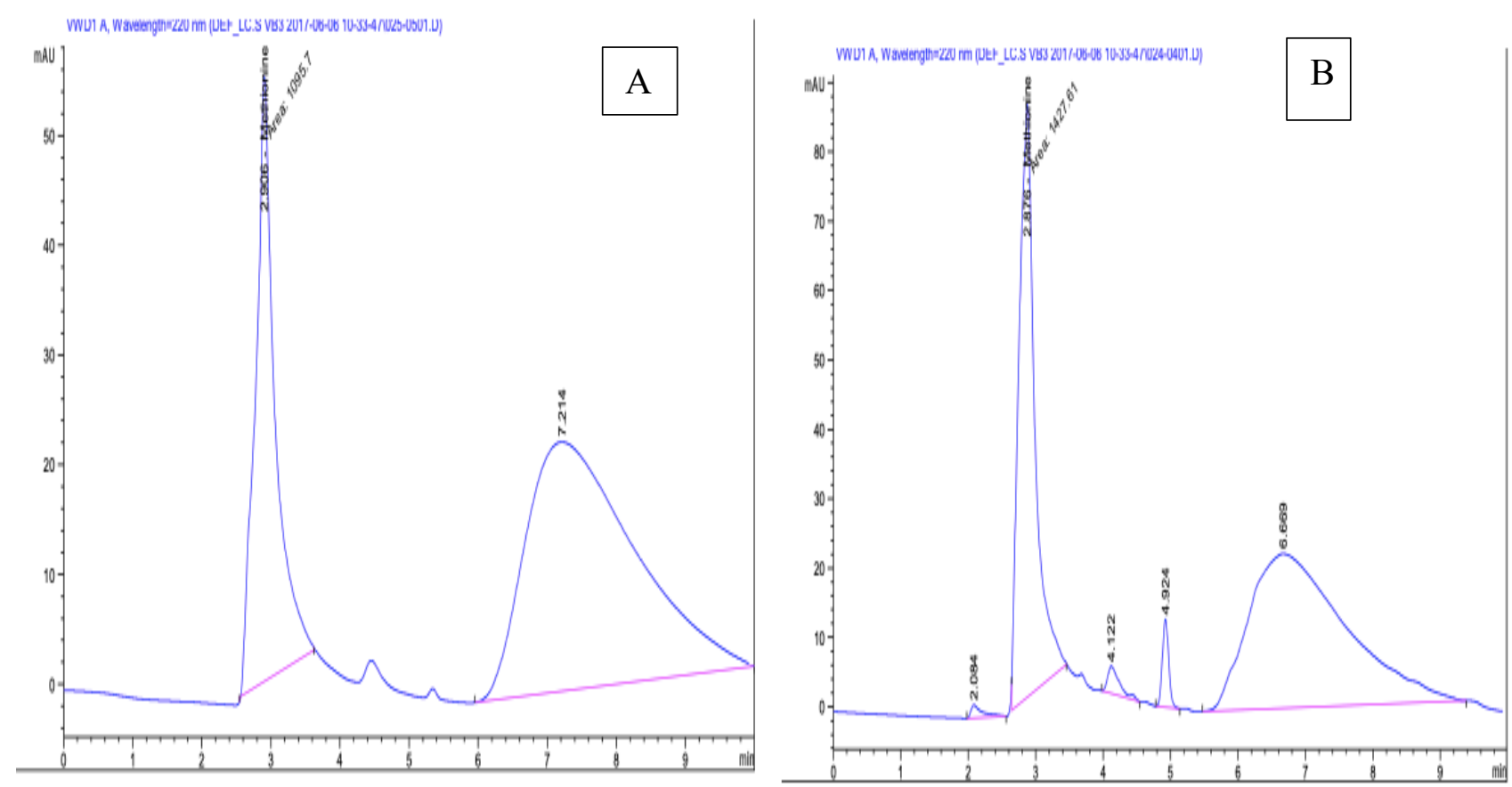

Figure 3: HPLC Spectra of Methionine Content of Site 1(a) and 2(b

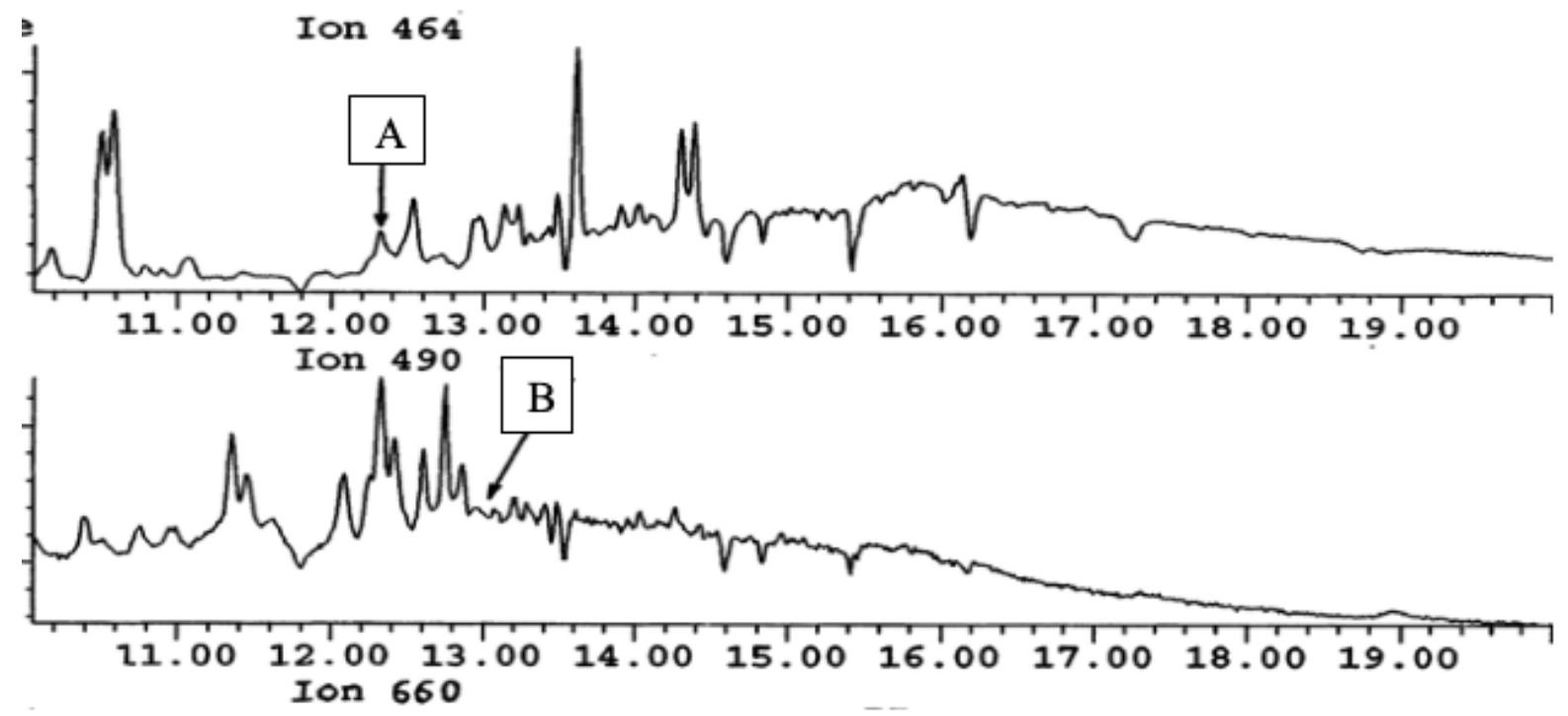

Figure 4: Chromatographic Spectra of estrone (a) and ethynylestradiol (b) 


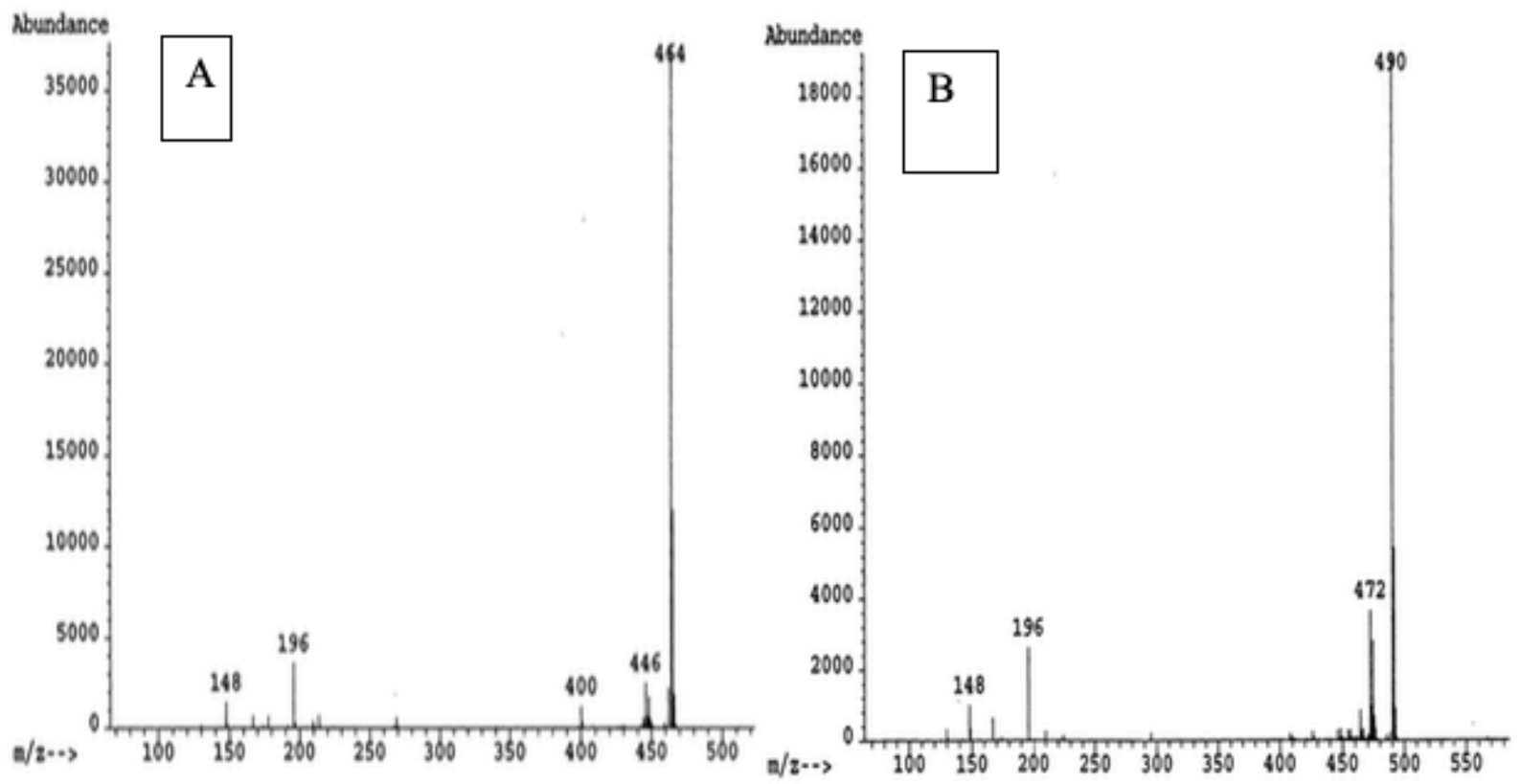

Figure 5: Mass Spectra derivative estrone (a) and ethynylestradiol (b)

Table 1: Macroscopic characteristics and $\mathrm{pH}$ of water samples from both sites

\begin{tabular}{lcccc}
\hline Samples & Colour & Smell & pH & Foreign matters \\
\hline Site 1 & Light Brown & None & 10.1 & Slight debris \\
Site 2 & Light Brown & None & 8.2 & Same as above \\
\hline
\end{tabular}

